УДК 373.3.091.6(091)(477)"18/19"

ORCID 0000-0003-2320-6100

Інна Петренко

\title{
ОРГАНІЗАЦІЯ ШКІЛЬНИХ ПРИМІЩЕНЬ І ПРОСТОРУ КЛАСНИХ КІМНАТ ПОЧАТКОВИХ ШКІЛ НА УКРАЇНСЬКИХ ЗЕМЛЯХ (кінець XIX - початок XX ст.)
}

Сучасна українська школа переживає серйозне реформування, зумовлене необхідністю забезпечення такого рівня підготовки учнів, який би відповідав новим вимогам інформаційного суспільства. Концепція «Нова українська школа» передбачає набуття учнями цілої низки компетентностей, тобто «динамічної комбінації знань, умінь, навичок, способів мислення, поглядів, цінностей, інших особистих якостей, що визначає здатність особи успішно соціалізуватися, провадити професійну та/або подальшу навчальну діяльність» [7]. Набуття компетентностей повинне відбуватися у відповідному освітньому середовищі. I це, насамперед, нове ставлення до дитини: повага, увага до неї та прагнення знайти оптимальний спосіб для іï ефективного навчання, це оновлені шкільні будівлі, класні кімнати, техніка, меблі.

Реалізація компетентнісного підходу передбачає високий рівень пізнавальної самостійності учнів, що зумовлює збільшення навчального навантаження дітей, знижує їхню мотивацію до навчання, негативно позначається на фізичному й психічному здоров'ї дітей. Це потребує повного дотримання закладами освіти санітарногігієнічних норм і правил облаштування класних кімнат. Сьогодні ситуація ускладнюється пандемією COVID-19, через яку запроваджені карантин, дистанційне навчання тощо. Міністерство освіти і науки України розробило «Рекомендації щодо організації роботи закладів загальної середньої освіти», у яких, зокрема, йдеться про зміни освітнього простору, дотримання нормативів наповнюваності класів, створення додаткового вільного простору, пропонується «з метою забезпечення соціальної дистанції під час навчання використовувати великі приміщення..., за сприятливих погодних умов забезпечувати проведення занять з окремих предметів на відкритому повітрі...» [17].

У таких умовах вивчення позитивного досвіду минулого дасть змогу максимально ефективно організувати простір класної кімнати початкової школи в умовах поширення коро- новірусної хвороби. Особливо цікавим вважаємо досвід періоду кінця XIX - початку XX ст., коли інтенсивний розвиток освіти зумовив потребу проєктування і будівництва шкільних приміщень, які саме у ті часи набули системного характеру. Тому практика проєктування шкіл й організації простору класних кімнат в Галичині та Центральній і Східній Україні заслуговує ретельного вивчення в умовах реалізації Концепції Нової української школи та побудови принципово нових для сучасної освіти шкільних приміщень. Аналіз початкових шкіл, збудованих в різних регіонах України в кінці XIX - на початку XX ст., особливостей організації простору класних кімнат, на нашу думку, дасть змогу не лише узагальнити наявні здобутки і досвід, але й виокремити національні особливості у проєктуванні, організації й використанні простору класних кімнат у структурі діяльності початкової школи.

Аналіз останніх досліджень і публікацій, у яких започатковано розв'язання цієї проблеми, i на які спирається автор; виділення нерозв' язаних раніше частин загальної проблеми, котрим присвячується авторська стаття.

Проблеми збереження здоров'я дітей в умовах шкільного навчання, організації освітнього простору, зокрема простору класної кімнати, не втрачає своєї актуальності впродовж декількох століть. Так, кінець XIX - початок XX ст. характеризувалися реформуванням системи вітчизняної народної освіти, зумовленим модернізацією економічної і соціальної сфер життя та викликаними нею змінами ставлення держави й суспільства до освіти. У зазначений період значно інтенсифікувався процес створення мережі закладів освіти різного типу. Відповідно, проблеми благоустрою, матеріально-технічного оснащення й санітарного стану закладів початкової освіти, а також їх впливу на фізичний й психологічний стан учнів викликали інтерес у тогочасних педагогів.

В історії вітчизняної освіти проблема організації простору класної кімнати практично не досліджена. Однак існує низка праць, у яких розкриваються окремі аспекти організації шкіл. 
Приміром, Н. Палопеженцева (1894), П. Виноградова (1912), аналізували гігієнічні умови навчання дітей у сільських школах; В. Звєрєв, К. Звєрєва, О. Гач (1989) вивчали матеріальнотехнічний стан сільських і недержавних закладів початкової освіти.

На облаштуванні класної кімнати як важливої складової освітнього середовища свого часу акцентував увагу В. Сухомлинський [12].

На початку XXI століття у працях архітекторів й істориків С. Беленцової, А. Татарнікова, О. Клевцової і Н. Жирова на основі аналізу законодавчих і статистичних джерел охарактеризовано технічний й санітарно-гігієнічний стан шкільних приміщень окремих регіонів царської Росії другої половини XIX - початку XX ст. [2; 13; 5].

Проблему організації простору сучасних шкільних приміщень досліджують українські педагоги В. Берц, Д. Косенко, Н. Карапузова, В. Помогайбо, $Є$. Починок, Т. Прибора та ін. [4; 9; 6].

Однак аналіз організації шкільних приміщень і простору класних кімнат початкових шкіл на українських землях кінця XIX - початку XX ст. у контексті дотримання санітарногігієнічних норм до сьогодні не проводився, що й зумовило вибір теми нашого дослідження.

Метою пропонованої розвідки є аналіз організації шкільних приміщень і класних кімнат початкових шкіл на українських землях в кінці XIX - на початку XX ст. як важливої складової освітнього середовища.

Наприкінці XIX - на початку XX ст. територія сучасної України знаходилася у складі двох імперій: Російської та Австро-Угорської; відповідно, розвиток регіонів України проходив досить своєрідно і повністю зумовлювався суспільними, соціокультурними чинниками тих держав, під владою яких знаходилися ті чи інші регіони. Водночас на українських землях у контексті соціально-політичних реформ в обох імперіях розвивалася освіта, при цьому найбільшими темпами система початкової освіти - масово відкривалися школи: грамоти, церковнопарафіяльні, міністерські, земські, народні й т.п. Зі свого боку це вимагало величезних фінансових витрат, однак постійний дефіцит бюджетних коштів не давав змоги повсюдно будувати нові, спеціально призначені для навчання дітей шкільні будинки, обладнувати їх відповідно до чинних навчально-методичних і гігієнічних рекомендацій. Переважно діти засвоювали ази грамоти в приміщеннях, абсолютно не пристосованих для навчання. Початкові школи організовувалися в церковних приміщеннях, волосних правліннях, простих селянських хатах тощо. С. Сірополко у праці «Історія освіти в Україні» наводив дані зі статистичних збірників, звітів, архівних матеріалів про технічні характеристики шкільних приміщень, стан яких повсюдно оцінювався як украй слабкий [11].

Наприкінці XIX ст. стало очевидним, що основна частина початкових шкіл була малопридатною для проведення занять і вони не відповідали призначенню. Сформувалася потреба швидкого масового будівництва зручних, якісних шкільних будинків. Саме у ці роки розпочалося активне співробітництво лікарівгігієністів, архітекторів і педагогів. Серед відомих праць того часу, у яких обгрунтовувалась потреба облаштування нових шкільних приміщень і простору класних кімнат, можна виділити дослідження педагогів, лікарів-гігієністів, архітекторів М. Гундобіна, А. Доброславіна, П. Лесгафта, Т. Мюнніха, Ф. Ерісмана й багатьох інших [22; 18; 20].

Будівництво початкових шкіл і в Галичині, і в Центральній та Східній Україні здійснювалося, головним чином, за індивідуальними проєктами окремих архітекторів. Аналіз наявних публікацій, окремих проєктів дає змогу виділити ключові особливості проєктування й будівництва шкільних будівель та організації простору класної кімнати в українських початкових школах.

Трансформація основного шкільного приміщення - класу - починалося з класу церковнопарафіяльної школи площею 120 м², який служив єдиним багатофункціональним приміщенням, де навчалися діти різних вікових груп. Поступово (на початок XX ст.) площа класу зменшилася до 60-72 м², з'явилися однакові вимоги до організації освітнього процесу, що стало підставою для розробки програм проєктування шкільних будинків. Водночас, у кожній губернії розроблялися відповідні правила для будівлі шкільних приміщень, облаштування класних кімнат, в основу яких були покладені розробки професора Ф. Ерісмана [10].

Відомий лікар-гігієніст Ф. Ерісман у 1875 р. опублікував проєкт зразкової класної кімнати 3 раціональним обладнанням [19; 8]. Так, Федір Ерісман вважав, що класна кімната - найважливіша частина шкільного приміщення, тому весь план школи має базуватися на тих вимогах, які висуваються до класної кімнати. Учений обгрунтував форму, абсолютні і відносні величини класної кімнати, зважаючи на особливості шкільного життя (необхідність з останніх місць чітко бачити написане на дошщі, чути те, що говорить учитель; умови освітлення, шкільна дисципліна і т.п.), необхідний об'єм повітря на кожну дитину, опалення, вентиляція, кількість місць для учнів, розміщення класної дошки і конторки учителя [18, с. 429].

Ф. Ерісман висував до класного приміщен- 
ня такі основні вимоги:

- довжина класного приміщення не більше 9-10 м, так як при більшій довжині вже погано видно букви на дошці;

- висота кімнати повинна бути не менше 4 м, так як при меншій висоті вікна виявляються занадто низькими і денного освітлення не вистачає. При більшій же висоті в кімнаті з'являються акустичні перешкоди;

- відношення площі вікон до площі підлоги дорівнює 1 : 5;

- вікна повинні розміщатися зліва від учнів, щоб тінь від руки не заважала дітям писати [20].

Питання освітлення були для Ф. Ерісмана одними 3 найбільш значущих, тому він у пояснювальній записці до своєї «зразкової класної кімнати» пропонував творчо осмислити необхідність організації широкого світлового фронту: «Очевидно, що тут потрібне певне групування вікон, певне зосередження світла саме там, де воно найбільш потрібне, і що шкільна архітектура повинна виробити щодо цього особливі мотиви, пристосовані до потреб класних кімнат. Найбільше цим потребам відповідає перетворення майже всієї зовнішньої стіни в одну суцільну віконну поверхню, з невеликим (в 1 аршин ширини на внутрішній поверхні) простінком по середині й більш широкими простінками в передній і задній частинах кімнати» [20, с. 5].

Цікавим і актуальним на сьогодні вважаємо твердження Ф. Ерісмана про недоцільність облаштування вікон за спинами учнів. Учений доводив, що «при письмі ці вікна дають привід до виникнення досить різких тіней від голови учнів, завдяки чому корисний на перший погляд вплив вікон, облаштованих за спиною учнів, повністю паралізується» [18, с. 433].

При звуковому навчанні грамоти до дошки рекомендували прибивати планочку й виставляти на неї рухливі літери, наклеєні на картон. У класі могло бути дві дошки, одна - розграфлена прямими лініями, а інша - косими. Шафи для книг у класній кімнаті пропонувалось робити в товщині стіни для економії простору приміщення, і з гігієнічного боку такі шафи перешкоджали скупченню пилу й бруду. Учительський стіл розташовувався на невеликій височині для того, щоб учитель бачив усіх учнів в класі [19].

Найчастіше школи, через одночасне скупчення багатьох людей у відносно тісному просторі, мали проблему з доступом достатньої кількості повітря. Для ії вирішення Ф. Ерісман пропонував штучну вентиляцію: влітку доступ кисню забезпечувався відкриттям вікон, взимку ж такий спосіб був небажаним, оскільки приміщення школи опалювалося, а потік повітря

з вікон швидко знижував температуру в класній кімнаті. Тому взимку повітря спеціально підігрівалося. Для підігріву повітря при будівництві печі між димоходами залишався порожній простір, відділений від димоходів цегельними стінками й не сполучений 3 ними, так звана камера. Ця камера з'єднувалася за допомогою труби, прокладеною під підлогою кімнати, із зовнішнім повітрям. Зовнішнє повітря входило по трубі в камеру, нагрівалося від дотику з гарячими стінками камери й виходило у кімнату через душники підігрітим [18].

Учений вважав, що «підлога класної кімнати повинна бути з поганого провідника тепла і бути дуже пильною. Найбільш доцільна та ідеальна підлога для класної кімнати - хороший дубовий паркет. Стіни повинні бути прохідні для повітря. Покриття масляною фарбою допускається до певної висоти (2 аршини), інша частина стін і стеля мають бути покриті звичайною клейовою фарбою. Панель може бути пофарбована в темно-сірий колір... Стеля має бути білою, матовою. Всі кути кімнати, а також і карниз округляються задля попередження застою в них повітря і зручності прибирання» [19].

Ф. Ерісман працював i над проблемою раціональної конструкції шкільних меблів; розробив шкільну парту власної конструкції, яка отримала згодом назву «парта Ерісмана», визначив основні вимоги до конструкції парти і іiі розмірів. Парти були не однакові: лікар розробив чотири ростові варіанти парт для дітей різного віку, при цьому і в класах радив менші парти розміщати біля дошки, більші - позаду. На нашу думку, революційною на той час була ідея ученого щодо того, що парти для дівчат і хлопців повинні були мати певні відмінності, оскільки зріст, довжина рук у них різна [8].

Наприкінці 80-х років XIX століття практично у кожній губернії на основі праць Ф. Ерісмана, рекомендацій лікарів-гігієністів розроблялися правила шкільного будівництва. Приміром, земські лікарі Харківщини виробили рекомендації щодо проєктування класних кімнат. Ці рекомендації було покладені в основу Правил шкільного будівництва, затверджених Харківськими губернськими земськими зборами у 1898 році. Ними встановлювались санітарні норми, пропорції співвідношення площі вікон до площі підлоги, мінімальний об'єм повітря, що мав приходитись на одного учня. У шкільному приміщенні передбачалось облаштування теплої роздягальні і аптечної шафки [15].

Це були одні $з$ перших документів, якими визначалися нормативи і технічні умови будівництва шкіл. Відповідно до них відомий україн- 
ський архітектор К. Жуков у 1913 р. розробив проєкт земської школи у Вовчанську Харківської губерніі. За цим проєктом передбачалося компактне розпланування приміщень (коли план будівлі наближається до квадрату): рекреаційна зала розташована в центрі, навколо неї розміщені класні приміщення, сходи знаходяться в кутах будівлі. Зовнішній вигляд школи був надзвичайно мальовничим і мав риси експресивності. За цим проєктом в різних місцях Вовчанського повіту було споруджено сім шкільних будинків (1913-1916 рр.).

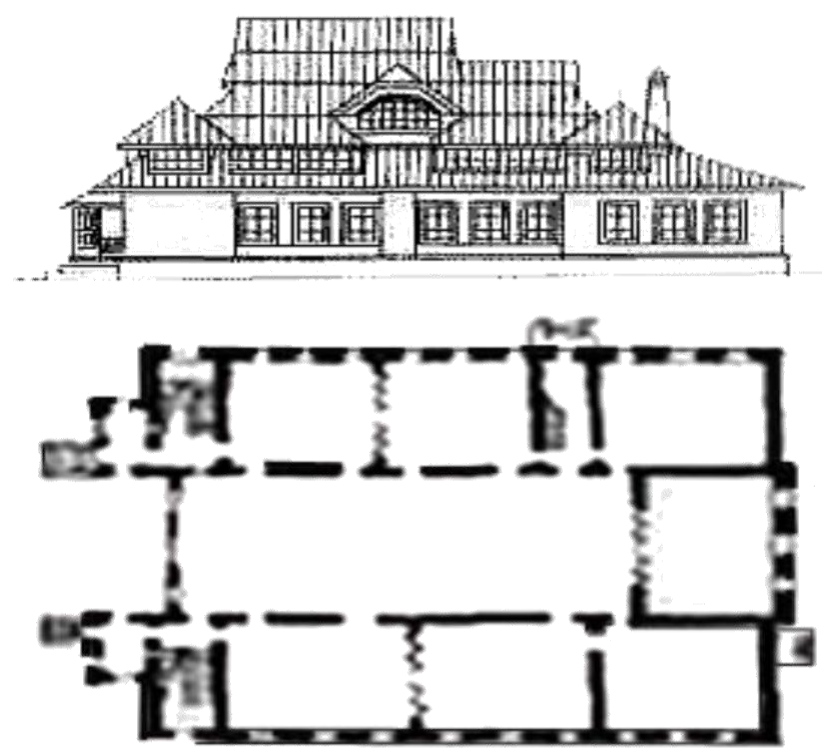

Рис. 1. Проєкт земсъкої иколи у Вовчанську ХаркіВської губернії К. ЖукоВа (1913) (фото з відкритих джерел Інтернету)

Школи були побудовані в новоукраїнському стилі [15]. Як зазначав український історик архітектури В. Чепелик, ті будівлі були «в багатьох значеннях надзвичайними, вони мали два поверхи 3 мансардою, їх корпус був незвичайно широким, бо досягав 28 м. Розпланування відзначалось неабиякою оригінальністю, бо середину корпусу займав великий зал - рекреація $\mathrm{i}$, за потребою, спортивний зал, - а навколо нього розміщувалися класи, що могли, в разі необхідності, об'єднуватись також у великі зали завдяки розсувним перегородкам поміж ними. То було сміливе, справді новаторське рішення внутрішньої композиції, яке тоді ще не мало аналогів у світовій архітектурі. Над заломрекреацією на горищному поверсі в мансарді влаштовували місцевий історико-етнографічний і природничий музей, завдяки чому школа ставала закладом навчання не лише дітей, але набувала значення культурно-просвітницького центру, який притягував мешканців села чи містечка» [15]. Таким чином, шкільна будівля ставала багатофункціональною, соціально значущою.

Натомість, школи 3 одностороннім розташуванням класів запропонував будувати відомий київський архітектор П. Альошин - всі класи у його проєктах зорієнтовані на один бік, а квартири, кабінети, учительське приміщення на інший. Різні за площею і конфігурацією вікна закривалися дерев' яними віконницями і сприяли збереженню тепла в холодну пору року і нічний час. Архітектор виконав низку конкурсних проєктів: зразкового чотирикласного училища в Києві (1903), реального училища у В’ятці (1905), комерційного училища в Казані (1906, 4-а премія), 1-ї (Ольгинської) гімназії в Києві (19041914). У 1920-1922 рр. П. Альошин створив 15 проєктів єдиної трудової школи для сіл Київської губернії [21].

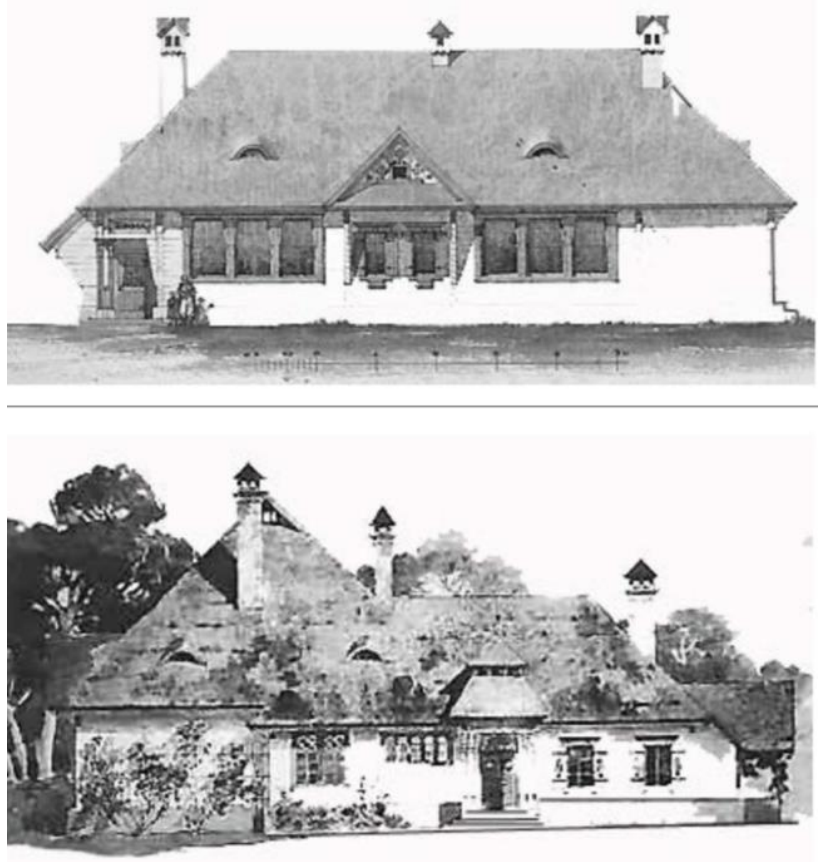

Рис. 2. Проєкти икіл для сіл Київської губерніӥ П. Альоиина (фото з відкритих джерел Інтернету)

У 1913-1916 роках український архітектор О. Сластіон створив серію 3 восьми проєктів земських шкіл, за якими було побудовано понад 50 земських шкіл у Лохвицькому повіті на Полтавщині на 1, 2 та 3 класи [14]. Приміщення шкіл будували у стилі українського архітектурного модерну - вони мали яскравий національно орієнтований вигляд: у всіх школах шестикутні вікна і вежі, цегляний декор на фасаді повторює український народний візерунок [3]. Проєкти О. Сластіона мали асиметричну композицію плану для одно- і двокомплектних земських шкіл і симетричну композицію для трикомплектних шкіл. У функціональному відношенні будівлі мали чітке зонування навчальних і допоміжних приміщень i повторювали собою традиційну 
схему української хати на дві половини (клас і квартира вчителя) або схему П-подібного типу [1].

У двокласних школах одна з кімнат була на одну третину менша від іншої. Це було пов' язане 3 тим, що в основному середньому відділенні займалося значно менше учнів, ніж у молодшому. У двокласних школах між двома приміщеннями, що призначалися для занять, планувалася перегородка зі зручними дверима. Це було передбачено, коли один учитель працював на два класи [1].

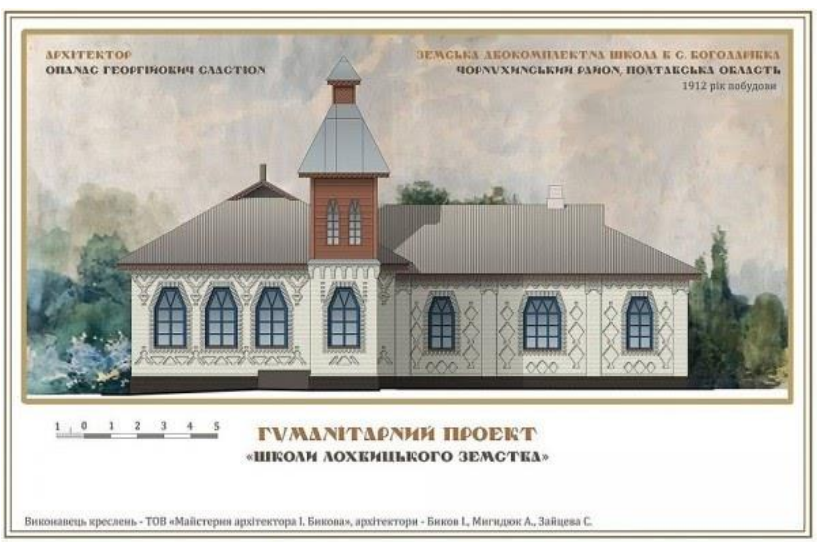

Рис. З. Проєкт икільного будинку О. Сластіона (фото з відкритих джерел Інтернету)

Цінним вважаємо те, що О. Сластіон збагатив композицію шкільного будинку, застосовуючи розсувні дерев'яні перегородки, які давали змогу у разі потреби об'єднувати класи між собою в одну велику залу. У той час подібні прийоми вирішення трансформованого внутрішнього простору майже не були відомі, тому в цьому О. Сластіон, як і К. Жуков, виступив новатором: він удосконалив композицію шкільного будинку і класної кімнати, підпорядковуючи планування вимогам доцільності до функціонального групування кімнат [1].

А в Галичині проєктування закладів освіти наприкінці XIX ст. здійснював архітектор Т. Мюнніх, як-то: численні індивідуальні народні та спеціалізовані школи, типові проєкти міських і сільських шкіл [16]. Він опублікував серію статей про шкільне будівництво в Галичині, видав каталог «Плани будинків народних шкіл», які сприяли поширенню шкільного будівництва [22]. Сьогодні проєкти Т. Мюнніха заслуговують уваги насамперед тому, що архітектор елементи традиційного національного будівництва Гуцульщини й Бойківщини застосував у проєктах освітніх закладів для підкреслення їx регіональної приналежності. Водночас, Т. Мюнніх віддавав перевагу функціональності, надійності, довговічності та економічності [16]. Планування шкіл повністю підпорядковувалося вимогам до- цільності, що проявилося у групуванні приміщень на дві функціональні зони: навчальну та житлову. Вікна класних кімнат розташовані виключно на східних і південних фасадах, їх площа збільшена порівняно 3 іншими приміщеннями школи. Типова будівля школи на один клас складалася 3 одного класу на 50 учнів, широкого (2 м) коридору 3 гардеробом та винесеного із загального об'єму тамбуру-входу. У житловій частині розміщені сіни, комора, кухня, дві кімнати вчителя. У двокласній будівлі класи проєктувалися на 80 і 50 учнів відповідно, ширина коридору навчальної частини була збільшена до 2,30 м. Архітектор розробив і описав інженерні рішення щодо вентиляції та опалювання шкіл [22].

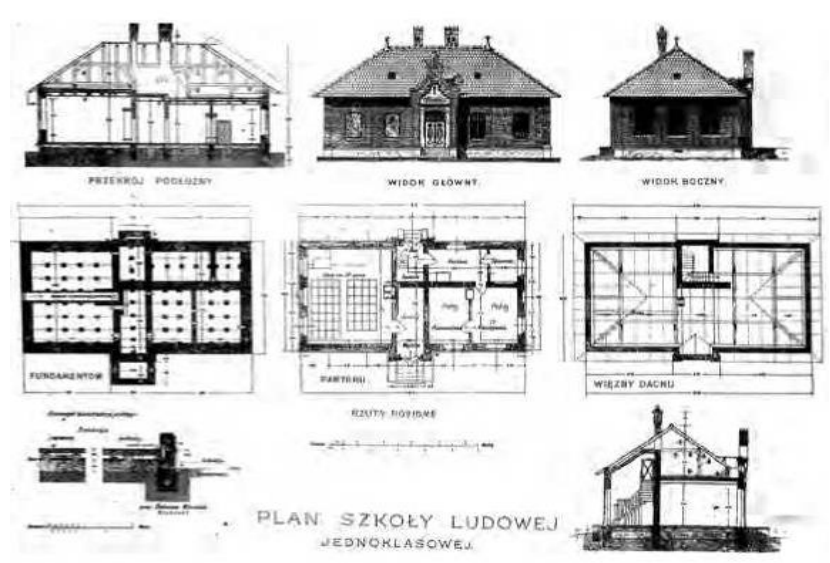

Рис. 4. Проєкти народних школи В Галичині Т. Мюнніха (фото з відкритих джерел Інтернету)

У своїх проєктах Т. Мюнніх пропонував плани пришкільної території, до якої входили шкільний двір, спортивний майданчик, пришкільна ділянка-город, господарські приміщення. Із західного та північного боків будівля школи була захищена великим пришкільним садом.

Аналіз проєктів шкільних будівель Т. Мюнніха дав змогу дослідникам його проєктів Л. Шулдан і А. Штендері стверджувати, що архітектор застосував прийом зміни висоти приміщень залежно від призначення; це дало йому змогу збільшити кубатуру класних кімнат до 27$30 \mathrm{~m}^{3}$, за дотримання вимоги виділення площі 0,75-0,8 м² на одного учня. Класи на 50 і 80 учнів спроєктовано ним, відповідно, площею близько 50 та понад 60 м². Т. Мюнніх детально обгрунтував «інженерні рішення щодо освітлення, вентилювання, обігрівання, водопостачання та водовідведення. Розміри віконних прорізів були різними: в класних кімнатах вікна розташовані так, щоб на робочі місця з лівого боку потрапляло природне світло. Площа світлопрозорих огорож призначена 3 розрахунку 1/4-1/6 площі підлоги класу (за розмірів вікон: 2,45 × 1,35; простінків - не більше 1,25 м; висоті підвіконня 
не вище 1 м)» [16].

При цьому організація простору класних кімнат передбачала розміщення учнівських столів у 2 ряди, у кожному ряду їх ставили до 10. За одним столом могли вільно сидіти четверо, бо ж на одне учнівське місце відводилася площа $50 \times 70$ см. На підвищенні - «градусі» 3 одного боку на планах розмістився стіл для вчителя, 3 іншого - «таблиця» (дошка) [16].

Особливо цінним вважаємо те, що проєкти шкільних будівель Т. Мюнніха вирізнялися своєрідністю, зорієнтованістю на власні західноукраїнські потреби і можливості.

Здійснений аналіз дає змогу зробити висновок про те, що кінець XIX - початок XX століття характеризується стабілізацією вимог до шкільних будівель, визначенням архітектурних, санітарно-гігієнічних і педагогічних вимог до функціональної організації простору класних кімнат.

На початок XX століття на українських землях, попри ідеологічні відмінності двох імперій і різні типи й підпорядкованість закладів освіти, склалася характерна картина, що відображала специфіку початкових шкіл:

- школи підрозділялися за кількістю класів, де проводилися заняття, на одно-, двох- і трикомплектні;

- шкільний будинок мав, крім класних кімнат, додаткові приміщення - роздягальню, кімнати вчителя й кухню;

- сільський шкільний будинок зазвичай не мав внутрішніх рекреацій, характерних для шкіл міських;

- у двох- і трикомплектних школах між двома класами пропонувалося влаштовувати розбірну перегородку заради перетворення класів у велику аудиторію при читанні лекцій для населення або при влаштуванні спектаклів. Розбірні перегородки рекомендувалося робити звуконепровідними.

Таким чином, організація простору класних кімнат в структурі діяльності початкових шкіл базувалася на основних досягненнях тогочасної науки та на дотриманні санітарногігієнічних, архітектурних і педагогічних норм.

Розробки українських архітекторів були прикладом для будівництва шкіл й організації простору класних кімнат в інших губерніях. Це, насамперед, проєкти шкільних будівель К. Жукова, П. Альошина, О. Сластіона, Т. Мюнніха, які можна вважати прикладом українського модерну кінця XIX - початку XX ст., позаяк в них застосовані композиційні прийоми традиційної української народної архітектури відповідних регіонів. Ці проєкти випереджали відомі при- клади типових будівель закладів освіти такого рівня. Схарактеризовані проєкти вирізнялися високою якістю виконання, функціональною продуманістю економічністю та довговічністю, дотриманням санітарно-гігієнічних і педагогічних вимог.

Отже, у досвіді будівництва шкільних будинків і організації простору класних кімнат в структурі діяльності початкових шкіл на українських землях досліджуваного періоду ми знаходимо важливі ідеї, які, безумовно, залишаються не тільки цікавими, але й корисними для сучасності. Це ті умови організації освітнього простору, дотримання яких є актуальним і на сьогодні: проєктування шкільних будинків відповідно до певних вимог, організація малокомплектних шкіл, внутрішнє обладнання школи, просторова організація класної кімнати. Найважливіша педагогічна ідея - це ідея адаптації освітнього простору класної кімнати до можливостей і потреб учнів, що є найважливішим чинником, який забезпечує результативність функціонування початкової школи і збереження здоров'я учнів.

Перспективи подальших наукових розвідок вбачаємо у вивченні нових підходів до організації простору класної кімнати в структурі діяльності початкової школи України у 20-30-х рр. XX ст.

\section{СПИСОК ВИКОРИСТАНИХ ДЖЕРЕЛ}

1. Аббасов А. М. Опанас Сластьон: Життя i творчість. Нарис. Київ: Мистецтво, 1973. 42 с.

2. Беленцов С. И. Санитарно-гигиеническое состояние средних общеобразовательных учреждений во второй половине XIX - начале XX веков. Современные наукоемкие технологии. 2005. № 1. C. 128-131.

3. Жук В. Н., Пустовіт Т. П. Наш рідний край: 3 історії освіти на Полтавщині в дореволюційний період: [збірник]. Полтава, 1991. № 12.

4. Карапузова Н., Починок $€$., Помогайбо В. Педагогічна ергономіка: створення комфортного та безпечного середовища у початковій школі. Постметодика. 2012. № 5(108). С. 8-12.

5. Клевцова О. В., Жиров Н. А. Школьные здания во второй половине XIX в.: технические и гигиенические требования (на примере Орловской губернии). История: фракты и симвоıЫ. 2016. № 9. С. 8-14.

6. Косенко Д. Ю. Простір сучасного шкільного класу: зонування та гнучка організація. Актуальні проблеми сучасного дизайну: збірник матеріалів Міжнар. наук.-практ. конф. (Київ, 20 квітня 2018 р.): у 2-х т. Київ: КНУТД, 2018. T. 2. C. $166-169$.

7. Нова українська школа. URL: https://mon.gov. ua/ua/tag/nova-ukrainska-shkola (дата звернення: 15.08.2020). 
8. Петренко І. Ф. Внесок лікаря-гігієніста Ф.Ф. Ерісмана (1842-1915) в організацію освітнього простору класної кімнати. Інноватика у вихованні. Рівне, 2019. Вип. 9. С. 62-82.

9. Прибора Т. Ергономічний підхід до організації інтер'єру класу. Рідна школа. 2017. № 3-4. C. 31-35.

10. Примерные планы школьных зданий на 40-60 и 60-100 учеников. Москва, 1898. 20 с.

11. Сірополко С. Історія освіти в Україні / Український Вільний університет; Друзі товариства імені Григорія Ващенка. Київ: Наукова думка, 2001. 912 с.

12. Сухомлинський В. О. Павлиська середня школа. Вибр. твори: в 5-ти т. Київ: Рад. шк., 1977. T. 4. C. 7-390.

13. Татарникова А. И. Санитарно-гигиенические условия обучения и здоровье школьников Западной Сибири в конце XIX - начале XX вв. Genеsis: исторические исследования. 2019. № 12. C. 10-24.

14. Чепелик В. Архитектура малых сельских школ начала XX века. Планировка, застройка и благоустройство сел Украинской ССР. Киев, 1981. Вып. 4.

15. Чепелик В. Український архітектурний модерн. URL: https://www.alyoshin.ru/Files/publika/ 4enelik/4enelik_05.html (дата звернення: 15.08.2020).

16. Шулдан Л. О., Штендера А. Ю. Архітектура народних шкіл у роботах Тадеуша Вацлава Мюнніха. Вісник Національного університету «Львівська політехніка». Серія: Архітектура. 2013. № 757. C. 424-433. URL: http://nbuv. gov.ua/UJRN/VNULPARX_2013_757_65 (дата звернення: 15.08.2020).

17. Щодо організації роботи закладів загальної середньої освіти у 2020/2021 навчальному році. URL: https://mon.gov.ua/ua/npa/shodoorganizaciyi-roboti-zakladiv-zagalnoyi-serednoyiosviti-u-20202021-navchalnomu-roci (дата звернення: 15.08.2020).

18. Эрисман Ф. Ф. Краткий учебник по гигиене. 3-е изд., испр. и доп. Москва: А. А. Карцев, 1912. 524 с.

19. Эрисман Ф.Ф. Соображения по вопросу о наилучшем устройстве классной мебели. Москва: тип. Э. Лисснера и Ю. Романа, 1895. $15 \mathrm{c}$.

20.Эрисман Ф.Ф. Соображения об устройстве образцовой классной комнаты. Москва, 1888. $10 \mathrm{c.}$

21. Ясієвич В. С. Кийвський зодчий П. Ф. Альошин. Київ: Будівельник, 1966. 66 с.

22. Münnich T. Budowa szkół ludowych w Galicji. Czasopismo Techniczne. Lwów: Organ. Towarzystwa Politechnicznego, 1898. № 24, S. 321-327.

\section{REFERENCES}

1. Abbasov, A. M. (1973). Opanas Slast'yon: Zhyttia i tvorchist'. Narys. Kyiv: Mystetstvo [in Russian].

2. Belentsov, S. I. (2005). Sanitarno-gigienicheskoe sostoyanie srednikh obshcheobrazovatel'nykh uchrezhdeniy vo vtoroy polovine XIX - nachale XX vekov. Sovremennye naukoemkie tehnologii, 1, 128-131 [in Russian].

3. Zhuk, V. N., Pustovit T. P. (1991). Nash ridnyi krai: $\mathrm{z}$ istorii osvity na Poltavshchyni v dorevoliutsiinyi period. Poltava, 12 [in Ukrainian].

4. Karapuzova, N., Pochynok, Ye., Pomohaibo, V. (2012). Pedahohichna erhonomika: stvorennia komfortnoho ta bezpechnoho seredovyshcha $\mathrm{u}$ pochatkovii shkoli. Postmetodyka, 5(108), 8-12 [in Ukrainian].

5. Klevtsova, O. V., Zhirov, N. A. (2016). Shkol'nye zdaniya vo vtoroy polovine XIX v.: tehnicheskie i gigienicheskie trebovaniya (na primere Orlovskoy gubernii). Istoriya: fakty $i$ simvoly, 9, 8-14 [in Russian].

6. Kosenko, D. Yu. (2018). Prostir suchasnoho shkilnoho klasu: zonuvannia ta hnuchka orhanizatsiia. Aktualni problemy suchasnoho dyzainu: zbirnyk materialiv Mizhnarodnoi naukovopraktychnoi konferentsii (Kyiv, 20 kvitnia 2018 r.) (Vols. 1-2); Vol. 2. Kyiv: KNUTD, 166-169 [in Ukrainian].

7. Nova ukrainska shkola (2016). URL: https:// mon.gov.ua/ua/tag/nova-ukrainska-shkola [in Ukrainian].

8. Petrenko, I. F. (2019). Vnesok likaria-hihiienista F. F. Erismana (1842-1915) v orhanizatsiiu osvitnioho prostoru klasnoi kimnaty. Innovatyka $u$ vykhovanni, Issue 9. Rivne, 62-82 [in Ukrainian].

9. Prybora, T. (2017). Erhonomichnyi pidkhid do orhanizatsii inter'ieru klasu. Ridna shkola, 3-4, 31-35 [in Ukrainian].

10. Primernye plany shkol'nykh zdaniy na 40-60 i 60-100 uchenikov. (1898). Moskva [in Russian].

11.Siropolko, S. (2001). Istoriia osvity v Ukraini / Ukrainskyi Vilnyi universytet; Druzi tovarystva imeni Hryhoriia Vashchenka. Kyiv: Naukova dumka [in Ukrainian].

12. Sukhomlynskyi, V. O. (1977). Pavlyska serednia shkola. Vybr. Tvory. (Vols. 1-5); Vol. 4. Kyiv: Rad. shk., 7-390 [in Ukrainian].

13. Tatarnikova, A. I. (2019). Sanitarno-gigienicheskie usloviya obucheniya i zdorov'ye shkol'nikov Zapadnoy Sibiri v konce XIX - nachale XX vv. Genesis: istoricheskie issledovaniya, 12, 10-24 [in Russian].

14. Chepelik, V. (1981). Arhitektura malykh sel'skikh shkol nachala XX veka. Planirovka, zastroyka $i$ blagoustroystvo sel Ukrainskoy SSR. Kiev, Issue 4 [in Russian]. 
15. Chepelyk, V. Ukrainskyi arkhitekturnyi modern. URL: https://www.alyoshin.ru/Files/publika/ 4enelik/4enelik_05.html [in Ukrainian].

16.Shuldan, L. O., Shtendera A. Yu. (2013). Arkhitektura narodnykh shkil $u$ robotakh Tadeusha Vatslava Miunnikha. Visnyk Natsionalnoho universytetu «Lvivska politekhnika». Seriia: Arkhitektura, 757, 424 433. URL: http://nbuv.gov. ua/UJRN/VNULPARX_2013_757_65 [in Ukrainian].

17. Shchodo orhanizatsii roboty zakladiv zahalnoi serednioi osvity u 2020/2021 navchalnomu rotsi. URL: https://mon.gov.ua/ua/npa/shodoorganizaciyi-roboti-zakladiv-zagalnoyi-serednoyiosviti-u-20202021-navchalnomu-roci [in Ukrainian].
18. Yerisman, F. F. (1912). Kratkiy uchebnik po gigiene. Moskva: A. A. Karcev [in Russian].

19. Yerisman, F. F. (1895). Soobrazheniya po voprosu o nailuchshem ustroistve klassnoi mebeli. Moskva: tip. Je. Lissnera i Ju. Romana [in Russian].

20. Yerisman, F. F. (1888). Soobrazheniya ob ustroystve obrazcovoy klassnoy komnaty. Moskva [in Russian].

21. Yasiievych, V. Ye. (1966). Kyivskyi zodchyi P. F. Alioshyn. Kyiv: Budivelnyk [in Ukrainian].

22. Múnnich, T. (1898). Budowa szkół ludowych w Galicji. Czasopismo Techniczne. Lwów: Organ. Towarzystwa Politechnicznego, 24, 321-327. 